\title{
Investigations on yellowing of chestnut crowns in Trentino (Alps, Northern Italy)
}

\author{
Daniela Bertoldi ${ }^{(1)}$, \\ Paolo Miorelli (1), \\ Federico Pedrazzoli (1), \\ Stefano Delugan (2), \\ Marco Deromedi ${ }^{(3)}$, \\ Giorgio Maresi ${ }^{(1)}$
}

\begin{abstract}
Yellowing of part or the whole canopy of chestnut trees was observed during the summer of 2014 in the areas of Tenno, Pranzo and Drena in Trentino, where chestnut cultivation is traditional on the lateral moraine deposit in a context of a prevalent limestone lithological substrate. Symptoms were observed on chestnut trees of different ages, either grafted or not, scattered or in stripes along the maximum slope. Investigations were carried out in the form of field surveys, chemical and molecular analyses of soil and leaves and greenhouse trials, to assess the damage evolution and its causes. No known pathogens emerged during the field surveys, and laboratory tests excluded the presence of phytoplasma infections. A comparison of yellow and asymptomatic leaves evidenced significant deficiencies of manganese $(\mathrm{Mn})$ and iron $(\mathrm{Fe})$ in the yellow leaves, though the level of the two nutrients was the same in the soil below green and yellowed trees. Experimental run-off trials in the greenhouse reproduced the foliage damage with a continuous basic water regime; open-field fertilizations with $\mathrm{Mn}$ and Fe led to a slightly recovery on the part of some treated leaves, thus confirming the hypothesis of a probable, sudden deficiency of the mentioned microelements. A possible explanation of this phenomenon could be, on one side, the high precipitation level of 2014, and, on the other side, the previous outbreaks of the Asian chestnut gall wasp, that had reduced foliage volume and thus the organic substance in the soil. The natural recovery from symptoms was clearly visible in trees after four years in a context of normal rainfall regime and increasing organic acid in the soil, after effective biological control of wasp. Even if related to a particular and rare geological condition, this is the first description of $\mathrm{Mn}$ deficiency in Castanea sativa.
\end{abstract}

Keywords: Chestnut Yellowing, Castanea sativa, Phytoplasmas, Foliar Deficiencies, Manganese

\section{Introduction}

Chestnut orchards are an important legacy in the Italian and Mediterranean mountains, where they have constituted one of the main assets for the survival of human populations for more than one thousand years (Pezzi et al. 2019, Conedera et al. 2004). Nowadays, chestnut orchards are still a key component of the Italian Alps and Apennines landscape, covering large surfaces, though most are now abandoned stands or were coppiced in the fifties of

the last century. A total surface of 788,408 ha (INFC 2007a, 2007b) of chestnut woods ( $9 \%$ of the forest surface in Italy) is concrete evidence of such a long history. Indeed, in several areas, chestnut orchards still represent an interesting, and sometimes fundamental or unique, economic resource, especially where "marron" production was maintained and carried on. Moreover, the presence of giant old trees, sometimes quite monumental, confers to chestnut orchards an interesting role for
(1) Fondazione Edmund Mach, Centre for Technology Transfer, Via E. Mach 1, 38010 San Michele all'Adige, TN (Italy); (2) Free worker, Trento (Italy); (3) Fondazione Edmund Mach, Research and Innovation Centre, Department of Sustainable Agroecosystems and Bioresources, San Michele all'Adige, TN (Italy)

@ Giorgio Maresi (giorgio.maresi@fmach.it)

Received: Apr 29, 2020 - Accepted: Aug 04, 2020

Citation: Bertoldi D, Miorelli P, Pedrazzoli F, Delugan S, Deromedi M, Maresi G (2020). Investigations on yellowing of chestnut crowns in Trentino (Alps, Northern Italy). iForest 13: 466-472. - doi: 10.3832/ifor3488-013 [online 2020-10-07]

Communicated by: Alberto Santini the maintenance of the biodiversity of plants, lichens, insects, and birds. This persistent economic and ecological importance enhances the concern about problems or perturbations able to affect chestnut. Of course, this concern is due to recent history, as these trees have dealt with three biological invasions in less than two hundred years (ink disease - Phytophthora cambivora (Petri) Buism.; chestnut blight Cryphonectria parasitica (Murr.) Barr; and the Asian gall wasp - Dryocosmus kuriphilus Yasumatsu), affecting both the plants and the confidence of growers. The general survival of chestnut stands to ink disease, the natural spread of hypovirulence (Turchetti et al. 2008), and the introduction of a specific parasitoid (Torymus sinensis Kamijo) for the biological control of wasps (Quacchia et al. 2008) have saved the orchards and their cultivation, but phytopathological problems have nonetheless influenced the management of stands, increasing their abandonment in many areas (Pezzi et al. 2011, 2017). Therefore, the appearance of any new symptoms must not be ignored, especially in the still cultivated areas. That is what happened in Trentino during the summer of 2014 when a sudden 
(and previously unseen) yellowing of chest nut trees was observed in Tenno, Campi, and Drena near Riva del Garda, one of the historical chestnut areas of the Province. Growers and foresters reported these new symptoms and investigations started quite immediately aiming at understanding and solving this new problem.

In this paper, we present the result of field observations and laboratory tests carried out in the last six years. The goals were to: (i) define the observed symptoms correctly; (ii) understand the possible environmental and pathological factors in volved; (iii) suggest proper and efficient management techniques of the affected trees and orchards.

\section{Materials and methods}

\section{Site description}

Yellowing of part or the whole crown was reported in only three chestnut sites in Trentino: Tenno (Loc. Pranzo), Campi and Drena. All these sites were located in lateral basins of the Lake valley (Sarca valley). Calcareous rocks belonging to the Calcari grigi group constitute the main lithological substrate. Glacial activity defined the valley's morphology, where small patches of chestnut orchards were planted in the range of the lateral moraine deposit (Castellarin et al. 2005).

These stands are centenary and repre sent a legacy of this traditional culture.

\section{Meteorological data}

Monthly accumulated precipitation data for the period 2002-2019 were obtained from the meteorological stations closest to the affected sites: Tenno ( $415 \mathrm{~m}$ a.s.l.), located at the basis of the affected slopes (Meteotrentino network), and Cavedine (552 m a.s.l. - FEM agro-meteorological network), located less than $7 \mathrm{~km}$ away from the study site of Drena. Only raw, non-validated, non-gap-filled meteorological data series were used.

\section{Field investigations and sampling}

In July 2015, after observing that crown yellowing was still present on the affected plants, field surveys were carried out in order to: (i) accurately describe the observed symptoms; (ii) examine affected plants for the presence of chestnut blight and ink disease symptoms; (iii) collect leaf samples from affected and healthy trees for laboratory analyses.

Fifty yellowed trees were accurately examined for disease symptoms: 30 in Tenno, 16 in Campi, and 4 in Drena. The presence of different types of cankers (Turchetti et al. 2008) was recorded and accurate inspections of the collar area were carried out to assess the presence of ink disease symptoms.

Twenty-eight sampling points (corresponding to 20 symptomatic and 8 asymptomatic trees, all marked and georeferred) were selected in the affected area and 25 leaves were randomly collected from the crown of each plant in July, every year from 2014 to 2016, and then in 2018. All samples were put into separate plastic bags, which were stored in a refrigerator bag and transported to the laboratory. Analyses were performed immediately. For each sample, all leaves were first examined for disease symptoms and yellowing degree, then five leaves were tested for phytoplasma presence and 20 leaves were analysed for macro and micro-nutrients determination. In total, 60 samples of symptomatic leaves and 40 of healthy leaves were collected. During this period, some trees were cut, and therefore not all 28 points were sampled each year.

Soil samples were collected in 2015 and in 2018 at the aforementioned 28 sites; each sample consisted of a mixture of four subsamples collected all around the crown of the chosen tree. In Pranzo, a larger amount of soil was picked up for the greenhouse trials. In this case, the soil was collected below symptomatic and green trees.

\section{Field fertilization trial}

Different fertilization treatments were applied to 18 out of the 20 yellowed trees previously chosen for foliage analysis. Pelleted chicken manure (3-5 kg per plant) was scattered under the crown of six trees. The crown of six other trees was sprayed with liquid manganese fertilizer (1.2 $\left.\mathrm{gr} \mathrm{l}^{-1}\right)$, while six others were treated with liquid iron fertilizer $\left(1.0 \mathrm{gr} \mathrm{l}^{-1}\right)$. The treatments were carried out in July 2015. The crown condition was assessed with a visual evaluation in September 2015.

\section{Greenhouse trials}

Two-year-old chestnut seedlings were potted with three different types of soil: peat, soil collected in the field under asymptomatic trees (control) and under yellowed ones (Pranzo). Twelve-litre pots were used for each seedling. Thirty-six plants were tested, 12 for each treatment; half of them were seedlings grafted with the local variety of marron, half were sylvatic ones. Two different water regimes were adopted for the trial: acid conditions $(\mathrm{pH}=6.6)$ and basic ones $(\mathrm{pH}=8)$, considering six plants for each soil condition in each regime. Plants were irrigated daily with two litres of water. The trial started in April 2016 and was carried out until September. Chlorophyll content was evaluated weekly by means of a SPAD-502 ${ }^{\circledR}$ (Konica Minolta sensing inc., Japan): five measures for each leaf on five leaves per plant were taken, totaling 25 measures for each plant.

\section{Laboratory tests}

\section{Phytoplasma detection}

The association between crown yellowing due to interveinal chlorosis on leaves and the presence of phytoplasmas in Italy had already been hypothesized, but not confirmed, by Mittempergher \& Sfalanga
(1998) and Vettraino et al. (2005). However, different phytoplasma species were detected in symptomatic Japanese chestnut trees, Castanea crenata Sieb. and Zucc., by microscope observations in the 1970 s (Okuda et al. 1974) and, more recently, also by molecular tools (Han et al. 1997, Jung et al. 2002, Lin et al. 2011) in Japan, in Korea and in China. Based on these data, the presence of phytoplasmas was assessed also in the symptomatic trees surveyed in this study.

Phloem tissue of leaves was obtained by isolating the midribs with a scalpel. Then, after lyophilization and homogenization, the total DNA was purified from around 15$20 \mathrm{mg}$ of dry material with the commercial kit NucleoSpin ${ }^{\circledast}$ Plant II (Macherey-Nagel $\mathrm{GmbH} \&$ \& Co. KG, Düren, Germany). The presence of phytoplasmas was assessed using a nested PCR assay with phytoplasma universal primers $\mathrm{P} 1$ (Deng \& Hiruki 1991)/P7 (Schneider et al. 1995), followed both by primers $\mathrm{fU}_{5} / \mathrm{rU}_{3}$ (Seemüller et al. 1998) and R16F2n/R16R2 (Lee et al. 1993). The nested-PCR products were electrophoresed on a $1.5 \%$ agarose gel stained with Midori Green Advance ${ }^{\circledast}$ (Nippon Genetics Europe, Düren, Germany) in TAE buffer and then visualized with a GelDoc ${ }^{\oplus}$ UV-transilluminator (BioRad, Segrate, Italy).

\section{Chemical analysis of soil}

Soil samples were air-dried and manually sieved $(<2 \mathrm{~mm})$. Soil reaction was determined in a 1:2.5 soil to water suspension using a $\mathrm{pH}$-meter equipped with a SenTix ${ }^{\mathrm{TM}} 41$ pH Electrode (INOLAB LEVEL 2, WTW, Weilheim, Germany). Total inorganic carbon was measured by a volumetric method with a Dietrich-Fruehling calcimeter according to ISO-10693 (1995) and expressed as g of $\mathrm{CaCO}_{3}$ per $\mathrm{kg}$ of soil, as well as active lime that was quantified by titration after reaction with ammonium oxalate $0.1 \mathrm{M}$ following the Drouineau method (Drouineau 1942).

The available fractions of $\mathrm{Fe}$ and $\mathrm{Mn}$ were extracted with a DTPA $0.005 \mathrm{M}, \mathrm{CaCl}_{2} 0.01 \mathrm{M}$ and triethanolamine $0.1 \mathrm{M}$ solution at $\mathrm{pH}$ 7.3 (Lindsay \& Norwell 1969) and measured with an inductively coupled plasma optical emission spectrometer (ICP-OES, Optima 8300, Perkin Elmer, Waltham, USA), after calibration with certified standard solutions.

\section{Chemical analysis of foliage}

After sampling, the leaf blades (without petiole) were washed with a $0.2 \%$ citric acid solution in order to remove dust and soil residues, and doubly rinsed with distilled water. The leaves were then ground and homogenized with a knife mill and ovendried at $70^{\circ} \mathrm{C} . \mathrm{P}, \mathrm{K}, \mathrm{Ca}, \mathrm{Mg}, \mathrm{S}, \mathrm{Mn}, \mathrm{Fe}, \mathrm{B}, \mathrm{Cu}$, and $\mathrm{Zn}$ contents were determined using an ICP-OES spectrometer after acid digestion with concentrated $\mathrm{HNO}_{3}(69 \%)$. Total nitrogen was quantified with an elemental analyzer (Vario Macro $\mathrm{CN}^{\circledR}$, Elementar Analysensysteme $\mathrm{GmbH}$, Hanau, Germany). 


\section{Statistical analysis}

As data were not normally distributed, significant differences in soil characteristics and in the macro and micro-nutrient contents of leaves were highlighted between test and yellowing thesis using the nonparametric Mann Whitney $U$ test.

For SPAD data, factorial ANOVA (with data, type of substrate and $\mathrm{pH}$ as factors) and the post-hoc Tukey's HSD test were performed, complying with the parametric test assumptions.

The statistical elaboration was carried out with Dell Statistica $64^{\circledR}$ version 13 (Dell Inc., Tulsa, OK, USA).

\section{Results}

\section{Symptom description}

The appearance of yellowing on the chestnut crown was first reported in July 2014 in all three mentioned sites. The same plants showed symptoms again in 2015 and, in most cases, also in the following years. Yellowing seemed to affect the whole crown in most of the observed trees but in some plants only part of the crown or single branches were interested. In Pranzo and Campi, most of the yellowed trees appeared clustered in clear stripes on the slopes following the maximum slope (Fig. 1a). On the other hand, in Drena the few affected trees were isolated. Both grafted and "wild" trees were affected by the yellowing, as well as young and old trees. The disorder seemed not to spread further during the observation period, remaining localized on the first affected trees: the monitored green ones maintained a normal appearance with no yellowing, while no new patches of yellowed trees appeared on a landscape scale. Only a few dominated and small trees appeared to get worse during the growing seasons, with twig diebacks and reduced foliation. No yellowed trees died during the observation period (2014-2018), but some of them were cut down by the owners.

The observed symptoms were the same for all the monitored trees: new leaves grew pale yellow with clear green veins; in several cases the leaf margins appeared first necrotized and then curled, finally assuming a distorted and scorched appearance that was more evident at the end of the season (Fig. 2). The foliage had a regular distribution on the crown, but yellowed leaves sometimes appeared to be smaller than green ones.

\section{Field investigations}

A clear predominance of hypovirulent infections of chestnut blight was observed on the examined trees. Healing and healed cankers (Turchetti et al. 2008) were present on almost all trees, while virulent infections were found sporadically and limited to small branches or sprouts.

Ink disease was observed on a single plant that died in 2016. All other yellowed trees had no evidence of collar coloniza-

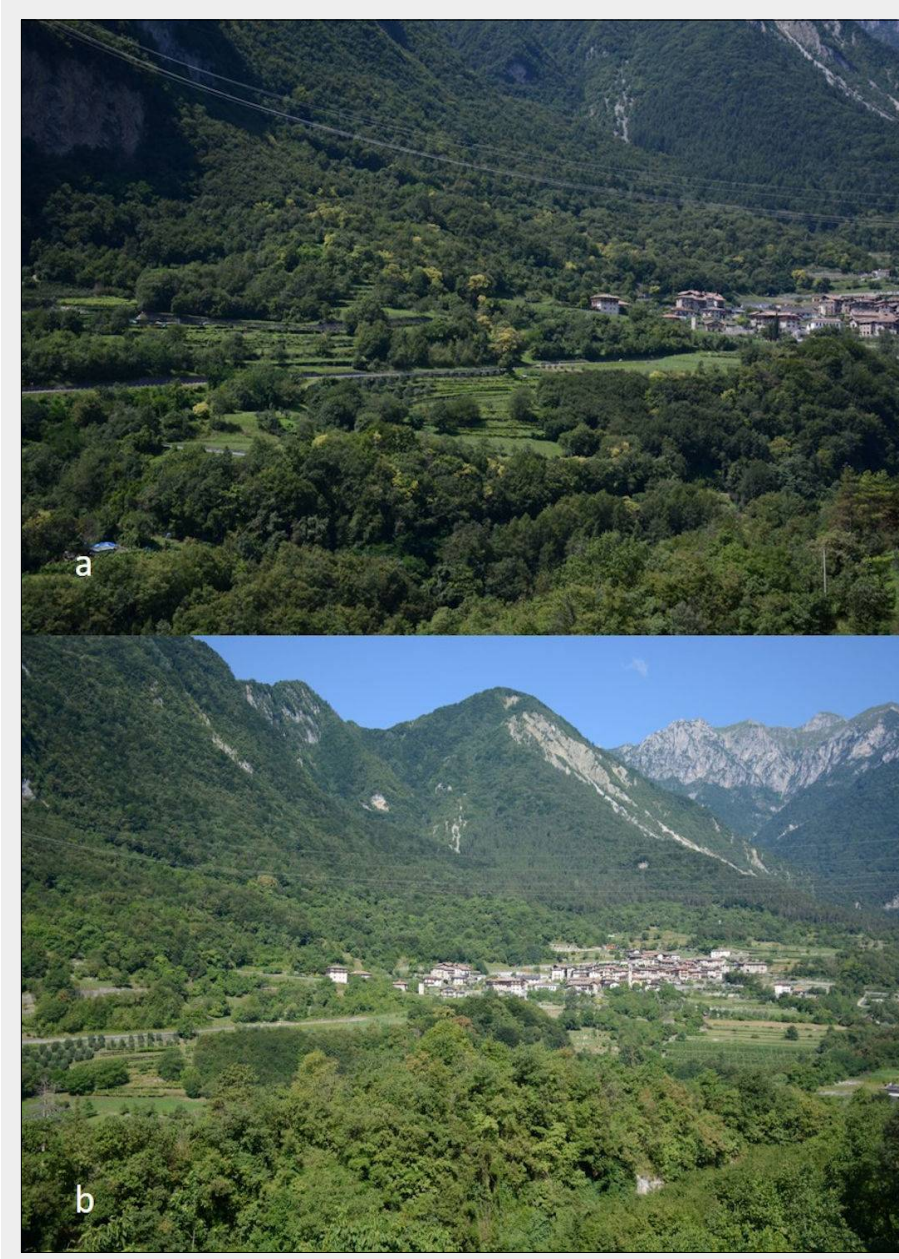

Fig. 1 - (a) Symptoms observed in the summer of 2014 in the Pranzo area: notice the stripes of yellowed trees on the slopes. (b) The area of Pranzo in July 2018: note the complete disappearance of symptoms and the recovery of most of the trees.

tion: no bark depression or browning were visible and under the bark no colonization with the characteristic dark-brown flameshaped lesions was observed. The presence of the chestnut gall wasp was observed on new leaves only sporadically, but previous heavy attacks on twigs and branches were still well evident on almost all trees.

\section{Meteorological data}

A clear increase of rainfall was reported for 2014, with more than $600 \mathrm{ml}$ above the average for both the examined meteorological stations (Fig. 3). This increase was more evident in the winter season, but continued throughout the vegetative season months. Interestingly, most of the winter precipitation was represented by rain rather than snow. The same trend was observed for the whole Trentino region.

\section{Field fertilization experiments}

Fertilization trials were carried out only once; they were subsequently abandoned due to the practical difficulty of distributing the fertilizers evenly on the crowns.

In any case, treated trees showed some response: greener leaves were observed in September in two out of six trees treated

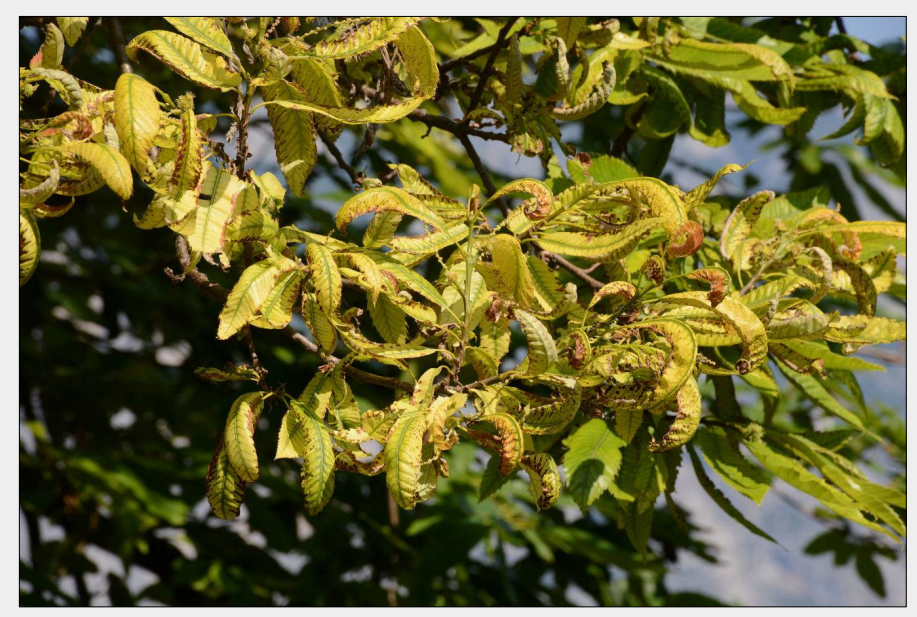

Fig. 2 - Symptomatic leaves: yellowed with green bands along the veins and curled and necrotic leaf margin. 
Fig. 3 - Annual rainfall for the period 2002-2019 recorded in the meteorological stations of

Tenno and Cavedine.

Fig. 4 - A chestnut seedling grown on Pranzo soil with continuous basic irrigation: leaves showed the same yellowing symptoms observed in the field.

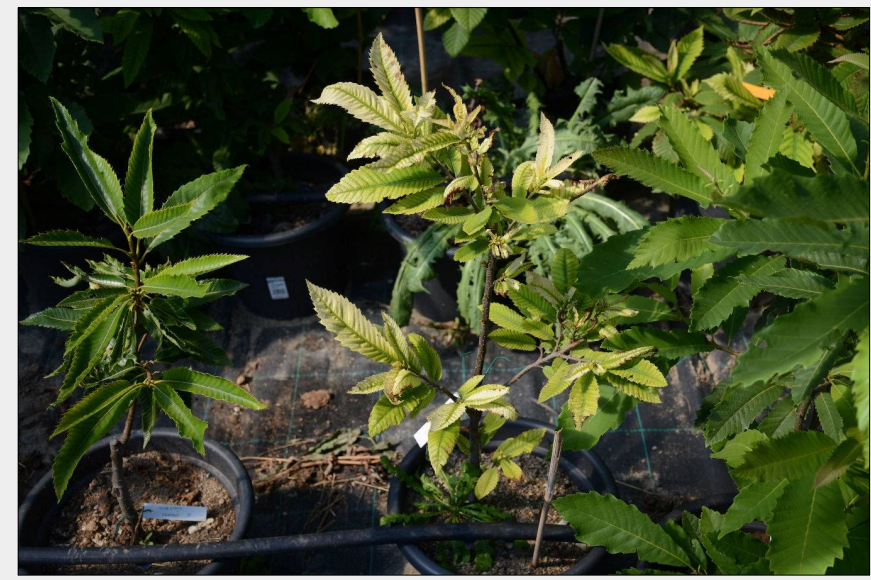

Tab. 1 - Monitored and treated trees in the investigated areas and their evolution between 2015 and 2018. (PR): partial recovered; (SR): slightly recovered (FR): fully recovered.

\begin{tabular}{|c|c|c|c|c|c|}
\hline $\mathbf{N}$ & Site & $\begin{array}{l}\text { Crown Status } \\
\text { June } 2015\end{array}$ & $\begin{array}{c}\text { Treatment } \\
2015\end{array}$ & $\begin{array}{c}\text { Crown Status } \\
\text { September } 2015\end{array}$ & $\begin{array}{l}\text { Crown Status } \\
\text { August } 2018\end{array}$ \\
\hline 1 & Drena & Yellow & $\mathrm{Mn}$ & Yellow & Yellow \\
\hline 2 & Drena & Yellow & Chicken manure & Yellow & Yellow branches \\
\hline 3 & Drena & Yellow 1 branch & Control & Yellow 1 branch & Yellow 1 branch \\
\hline 4 & Drena & Yellow & $\mathrm{Fe}$ & Yellow & Yellow \\
\hline 5 & Drena & Green & - & Green & Green \\
\hline 6 & Drena & Green & - & Green & Green \\
\hline 7 & Drena & Green & - & Green & Green \\
\hline 8 & Drena & Green & - & Green & Green \\
\hline 9 & Pranzo & Yellow & Control & Yellow & Green (FR) \\
\hline 10 & Pranzo & Yellow & $\mathrm{Fe}$ & Green (PR) & Green (FR) \\
\hline 11 & Pranzo & Yellow & $\mathrm{Mn}$ & Green (PR) & Green (FR) \\
\hline 12 & Pranzo & Yellow & Chicken manure & Yellow & Green (FR) \\
\hline 13 & Pranzo & Green & - & Green & Green \\
\hline 14 & Campi & Yellow & $\mathrm{Fe}$ & Green (PR) & Green (FR) \\
\hline 15 & Campi & Yellow & Chicken manure & Yellow & Green (FR) \\
\hline 16 & Campi & Yellow & $\mathrm{Mn}$ & Green (SR) & Green (FR) \\
\hline 17 & Campi & Yellow & Control & Yellow & Green (FR) \\
\hline 18 & Campi & Green & - & Green & Green \\
\hline 19 & Pranzo & Yellow & $\mathrm{Fe}$ & Green (SR) & Green (FR) \\
\hline 20 & Pranzo & Yellow & $\mathrm{Mn}$ & Green (PR) & Green (FR) \\
\hline 21 & Pranzo & Yellow & Control & Yellow & cut \\
\hline 22 & Pranzo & Yellow & Chicken manure & Yellow & Yellow \\
\hline 23 & Pranzo & Green & - & Green & Green \\
\hline 24 & Pranzo & Yellow & Chicken manure & Green (SR) & Green (FR) \\
\hline 25 & Pranzo & Yellow & $M n$ & Green (SR) & Green (FR) \\
\hline 26 & Pranzo & Yellow & $\mathrm{Fe}$ & cut & cut \\
\hline 27 & Pranzo & Yellow & Control & Yellow & Green (PR) \\
\hline 28 & Pranzo & Green & - & - & Green \\
\hline
\end{tabular}

with $\mathrm{Mn}$ and in one out of six of those treated with Fe (Tab. 1). Only the lower branches showed this slight improvement, while most of the crown maintained the yellowish appearance. Chicken manuring had no effect on crown recovery. Controls, yellow and green ones, showed no change in their crown condition.

In 2018 most of the monitored yellow trees showed a complete or partial recovering (Tab. 1, see also Fig. S1 in Supplementary material), while no spread of the symptoms was observed in the monitored green ones. This recovery appeared evident in the whole area of Pranzo and Campi (Fig. 1b), while the affected trees of Drena showed little or no recovery: two trees maintained the yellow appearance of the whole crown, while in the other only single branches continued to show yellow foliage.

\section{Greenhouse trials}

Both grafted and non-grafted seedlings exhibited a similar behaviour during their growth: yellowing and a reduced leaf dimension were observed in the treatment growing on soil collected in the field; these symptoms were recorded only in the plants with a basic water regime, while trees irrigated with acidic water showed a quite regular growth and no anomalies in the foliage. The symptoms developed in the greenhouse resembled those observed in the field (Fig. 4).

SPAD data enhanced the different behaviour of the treatments. In general, seedlings planted in soil coming from the affected area and with basic irrigation water ("Pranzo $\mathrm{pH}=8$ ") showed the worst performance, in terms of chlorophyll content, during the whole period of observation. The average SPAD values for this treatment (30) were significantly $(p<0.05)$ lower than "Peat $\mathrm{pH}=8$ " (mean value $=34$ ) and "Control pH=6.6" (mean = 33), whereas the difference with "Peat $\mathrm{pH}=6.6$ " (mean = 39) and "Pranzo $\mathrm{pH}=6.6$ " ( mean $=38)$ was highly $(p<0.001)$ significant. On the contrary, the difference with "Control $\mathrm{pH}=8$ " (mean value $=32$ ) was not statistically significant. "Peat $\mathrm{pH}=6.6$ " generally showed the best results, but "Pranzo $\mathrm{pH}=6.6$ " also performed well, the Spad values of these 2 theses being significantly $(p<0.001)$ higher than all others and performing distinctly better than their homologous in basic conditions. Interestingly, an intermediate behavior was recorded for the seedlings under "Peat $\mathrm{pH}=8$ " treatment. The differences among treatments were more evident and significant after the middle of July (Fig. 5 ). The great difference in the SPAD values recorded at $\mathrm{pH}=6.6$ and at $\mathrm{pH}=8$ for "Pranzo" suggests a higher influence of the acidity of the soil solution collected under symptomatic trees compared to the "Control" and "Peat" (Fig. S2 in Supplementary material). 
Fig. 5 - Chlorophyll content (mean value $\pm \mathrm{SE}$ ) measured by a SPAD-502 in the leaves of chestnut seedlings potted in soil collected on the field under yellowed (Pranzo) and asymptomatic (Control) trees and in peat. The three soil combinations were irrigated with acid $(\mathrm{pH}$ = 6.6) and basic $(\mathrm{pH}$ $=8$ ) water.

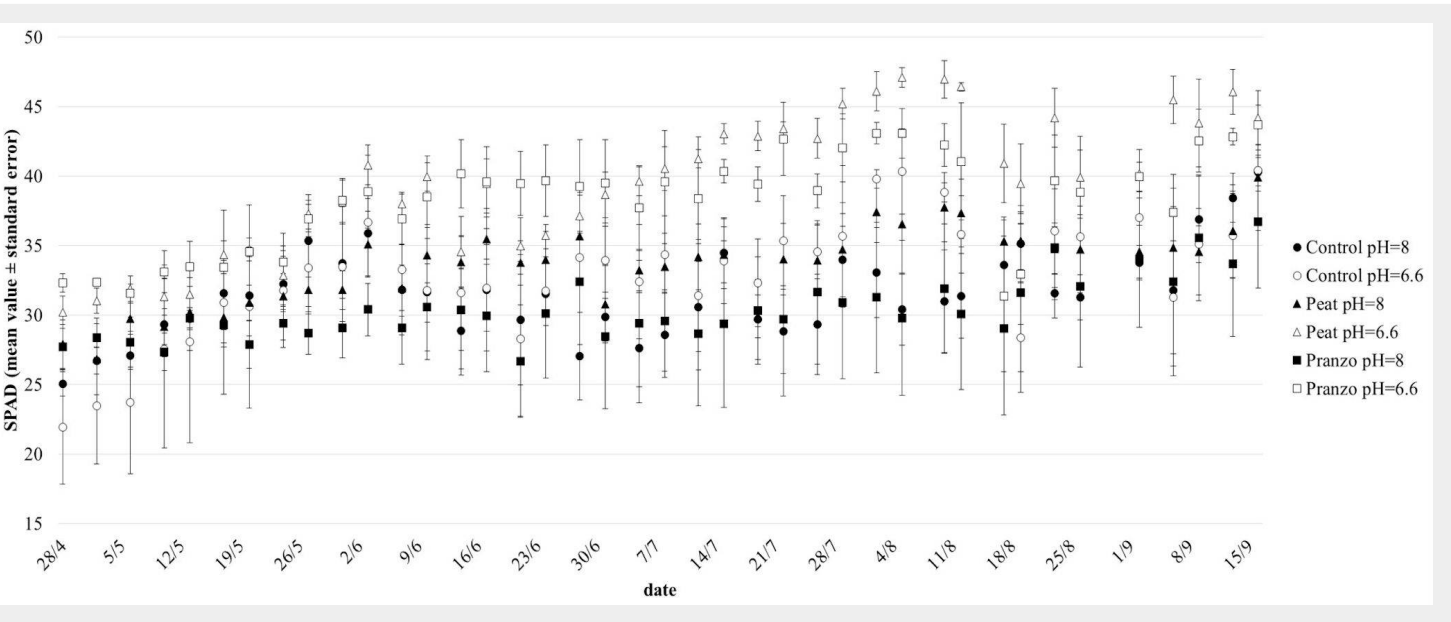

\section{Laboratory tests}

\section{Phytoplasmas detection}

A total number of 83 leaf samples $(59$ collected from yellowed trees and 24 from asymptomatic ones) were analysed for the presence of phytoplasmas using the universal primers $\mathrm{P}_{1} / \mathrm{P}_{7}$, followed by the $\mathrm{fU}_{5} /$ rU3 and R16F2n/R16R2 primers. No sample tested positive for the presence of phytoplasmas, either in direct or nested PCR.

\section{Chemical analysis of soil}

The soil reaction for healthy trees ranged between 5.4 to 7.8 (median 7.3) whereas for yellowing trees range between 6.5 and 8.1 (median 7.6). Total inorganic carbon ranged between non-detectable $(<10 \mathrm{~g}$ $\mathrm{CaCO}_{3} \mathrm{~kg}^{-1}$ ) and about $400 \mathrm{~g} \mathrm{CaCO}_{3} \mathrm{~kg}^{-1}$ for both groups, with median values of 84 and $104 \mathrm{~g} \mathrm{CaCO}_{3} \mathrm{~kg}^{-1}$, respectively, in the growing soil of test and yellowing trees. Active lime varied between $<10$ and $63 \mathrm{~g} \mathrm{CaCO}_{3}$ $\mathrm{kg}^{-1}$ (median $<10 \mathrm{~g} \mathrm{CaCO}_{3} \mathrm{~kg}^{-1}$ ) for test soils and $<10$ and $90 \mathrm{~g} \mathrm{CaCO}_{3} \mathrm{~kg}^{-1}$ (median $11 \mathrm{~g}$ $\mathrm{CaCO}_{3} \mathrm{~kg}^{-1}$ ) for yellowing soils. Available $\mathrm{Fe}$ and $\mathrm{Mn}$ ranged respectively from 10 to 134 $\mathrm{mg} \mathrm{kg}^{-1}$ (median $30 \mathrm{mg} \mathrm{kg}^{-1}$ ) and from 4.4 to $32.9 \mathrm{mg} \mathrm{kg}^{-1}$ (median $13.3 \mathrm{mg} \mathrm{kg}^{-1}$ ) in test soils and from 19.4 to $41.3 \mathrm{mg} \mathrm{kg}^{-1}$ (median $26.4 \mathrm{mg} \mathrm{kg}^{-1}$ ) and from 9.3 to $10.3 \mathrm{mg} \mathrm{kg}^{-1}$ (median $9.5 \mathrm{mg} \mathrm{kg}^{-1}$ ) in yellowing soils. All these differences were not statistically significant ( $p>0.05-$ Tab. S2 in Supplementary material).

\section{Chemical analysis of foliage}

Fig. 6 shows macro and micronutrient content distributions in test and yellowing leaves. Fe and $\mathrm{Mn}$ contents were significantly $(p<0.001)$ higher in the test than in yellowing leaves while $P, K$, and $S(p<0.05)$, as well as $\mathrm{Ca}, \mathrm{Mg}$ and $\mathrm{B}(\mathrm{p}<0.01)$ were significantly higher in the latter. $\mathrm{N}, \mathrm{Zn}$, and $\mathrm{Cu}$ were not significantly different in the two groups (Tab. S2 in Supplementary material).

\section{Discussion and conclusion}

Chemical analyses clearly evidenced how the observed symptoms were related to a mineral deficiency involving Fe and, mainly,
Mn. The hypothesis was confirmed by the liage appearance of symptomatic trees reresult of the greenhouse trials and by the sembles that described for other species slight recovery of the leaves treated with suffering from Mn deficiency: the yellowliquid $\mathrm{Mn}$ or Fe fertilizer. Moreover, the fo- whitish colour with the marked green of
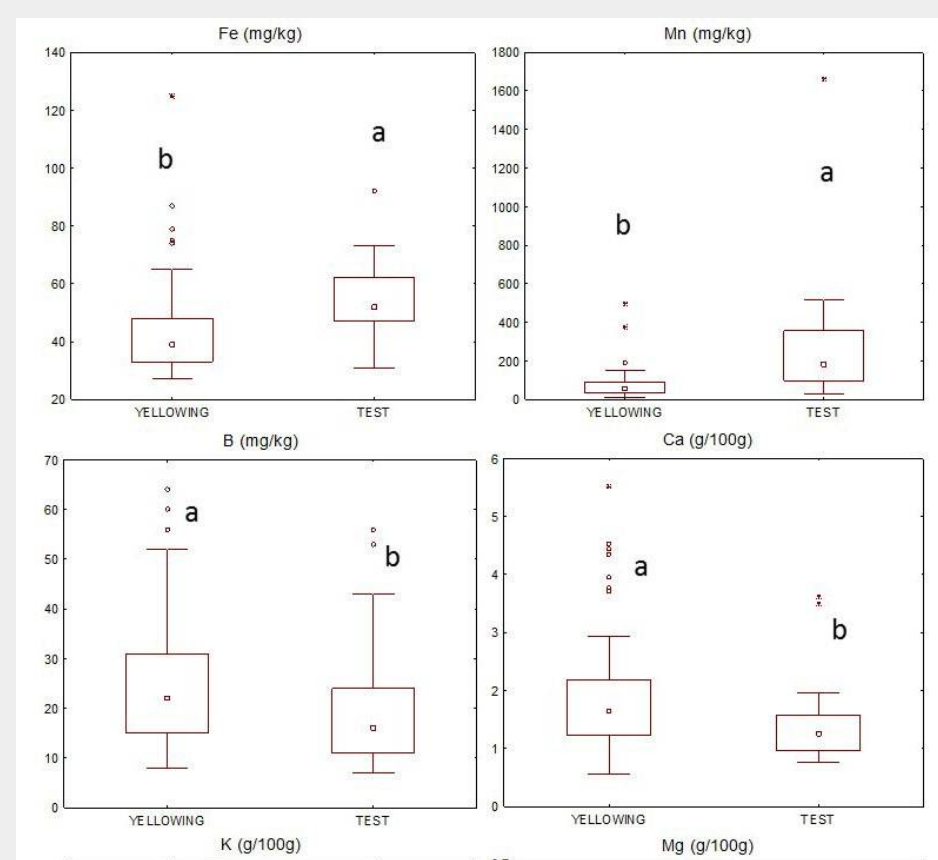

Fig. 6 - Boxplot of the distribution of Fe, Mn, B, Ca, K, Mg, P and $S$ in test and yellowing leaves collected in the field. Asterisks: outliers; central square: median value. Different letters indicate significant differences ( $p<0.05)$ between test and yellowing samples. 
the veins is reported as characteristic for this deficiency, and so are the necrosis and the curling of the leaf margin (Costello et al. 2003). This provides support to the hypothesis that these new symptoms observed in C. sativa were, in the examined localities, strictly related to a mineral deficiency involving the adsorption of $\mathrm{Mn}$. Even if the current knowledge about the nutritional status of $C$. sativa is still insufficient, B and Mg deficiencies have been reported in Portugal by Portela et al. (2010). These authors suggested a strong Mn competition against $\mathrm{Mg}$ in acidic soils, while Laroche et al. (1997) reported that the Mn content in foliage was strongly and negatively affected by the $\mathrm{pH}$ increase also in chestnut seedlings. In our study, the yellowing leaves showed lower $\mathrm{Fe}$ and $\mathrm{Mn}$ and higher $\mathrm{Ca}$ and $\mathrm{Mg}$ contents than the healthy ones. In detail, $\mathrm{Mn}$ content in both theses is decidedly lower than the values reported in the literature as adequate (Toprak \& Seferoglu 2013, Arrobas et al. 2018, Toprak 2019). Chestnut grows preferentially on acidic soil and, for this reason, a $\mathrm{Mn}$ deficit is rarely reported, while antagonism or toxicity phenomena are highlighted (Portela et al. 2010). However, on calcareous soils like those of the investigated stands, a pH increase could lead to a decrease in $\mathrm{Mn}$ availability. In all cases, the link between $\mathrm{CaCO}_{3}$ and its related high $\mathrm{pH}$ value with $\mathrm{Mn}$ deficiency is well known (Costello et al. 2003) and here, for the first time, it is reported also in C. sativa in relation to symptomatic manifestations.

The presence of yellows diseases was observed in the Japanese chestnut, Castanea crenata Sieb. and Zucc., in the 1950s in Japan (Shimada \& Kouda 1954) and then associated with phytoplasmas by Okuda et al. (1974). Phytoplasmas causing diseases on chestnut were observed also in Korea (Han et al. 1997, Jung et al. 2002) and more recently in China (Lin et al. 2011).

What we observed in Trentino is similar, if not equal to the chestnut yellowing described by Mittempergher \& Sfalanga (1998) in the northern Apennines and in two Trentino sites, far from the ones investigated in this paper. Antonaroli \& Perna (2000) reported similar phenomena in both the Emilia Romagna and Marche regions: foliage symptoms were reported, including yellowish, browning and curling of the leaf margin exactly like those observed in Trentino. In both cases, there was no evidence of soil disorders or weather anomalies, even if the mentioned Trentino sites were located in a limestone area. Moreover, no phytoplasmas or other agents were identified in the affected trees. Again, in the Marche region, similar symptoms proved to be transmissible in grafting trials, but neither viruses nor phytoplasmas were detected in the affected plants (Vettraino et al. 2005). Interestingly, also in all these cases the symptoms were very localized (mainly on single trees or stands) and were not spreading further during the years. At present, yellowing on C. sativa in Italy seems not to be related to phytoplasmas, as confirmed by our laboratory tests, and its symptoms seem dissimilar and different from those reported in Japan, Korea or China. Probably due to its reduced spread, its unclear or never confirmed association with pathogens, such as phytoplasmas, and its sudden disappearance, "Chestnut yellows" was therefore removed from the EPPO Alert list in 2001 (EPPO 2001).

Even the natural recovery of most trees seems to confirm the lack of microelements as the main cause of the phenomenon. Interestingly, recovery happened in very few years; only some trees, especially in Drena, continued to show symptomatic leaves (generally on single branches), suggesting that the local soil condition and composition could still play a role in the appearance of yellowing.

Why did a similar disorder suddenly appear on already adult, if not veteran, trees? Chestnut cultivation on the same soil in the interested areas has a centenary history, with no record of similar problems. Moreover, the $\mathrm{Mn}$ and Fe contents in the soil collected below affected and healthy trees were similar, with no problematic values. Observed values were lower than those reported by Toprak (2019) but higher or consistent with those shown by Toprak \& Seferoglu (2013) and Dengiz et al. (2011) for horizons characterized by a high carbonate content. Therefore, the observed disorder could be due to some specific and unique causes. First, the role of heavy precipitations in 2014 is clearly identifiable, because a larger amount of rainfall was registered during all the winter months both in the considered meteorological station and in the whole of Trentino and Northern Italy. It is conceivable that an almost continuous and larger amount of basic soil solution could have created a temporary $\mathrm{Mn}$ and Fe uptake deficiency. The pattern of the yellowing distribution along the slope suggests the possible role of the main drainage routes in creating a preferential area for this disorder. Anyway, a basic soil solution is probably the rule in this geological and pedologic context and it is possible that similar situations might have happened also in the past, without causing any problem. In addition, another factor could have played a substantial role: the progressive depletion of organic substance due to incorrect soil management techniques (i.e., burning of leaves - Vittori Antisari et al. 2013), or to the effect of several years of chestnut gall wasp presence. Indeed, this parasite had a strong influence of leaf production and growth (Maltoni et al. 2012, Ugolini et al. 2014, Gehring et al. 2018): a thinner and almost transparent crown was the most evident sign of infected trees, so the spread of the parasites could have caused a heavy reduction of the organic substances present also in the investigated contexts. This means much less humic organic acids in the soil, enhancing or, rather, not buffering, the quite basic soil solution as usual. Moreover, natural recovery happened after the improvement of the crown condition due to the beneficial effects of the biological control of $D$. kuriphilus, with a marked reduction of affected leaves already visible in 2014 .

Therefore, a "perfect storm" due to a reduced organic acid presence in the soil mainly caused by the chestnut gall wasp and by a continuous and conspicuous basic soil circulating solution, could have caused the onset of this new symptomatology. This case study emphasized again the role of soil in chestnut orchards, not only in these particular sites, characterized by chestnut on limestone, rare situation in the Italian context: a better persistence of organic substances needs to be a management goal, if one wishes to avoid new problems due to abnormal weather and climatic conditions.

\section{Acknowledgments}

We would like to thank Angiolino Bertoni, Riccardo Pasquazzo, Stefano Baldi for their field assistance and Christian Cainelli for laboratory analysis.

\section{References}

Antonaroli R, Perna MR (2000). Una fitopatia ad eziologia ancora incerta: il giallume del castagno in Emilia-Romagna e nelle Marche [An uncertain disease: yellowing of chestnut in EmiliaRomagna and Marche]. Sherwood 57: 43-46. [in Italian]

Arrobas $M$, Afonso S, Angelo Rodrigues $M$ (2018). Diagnosing the nutritional condition of chestnut groves by soil and leaf analyses. Scientia Horticulturae 228: 113-121 - doi: 10.1016/j.sci enta.2017.10.027

Castellarin A, Picotti V, Cantelli L, Claps M, Trombetta L, Selli L, Carton A, Borsato A, Daminato F, Nardin M, Santuliana E, Veronese L, Bollettinari $G$ (2005). Note illustrative della carta geologica d'Italia alla scala 1:50.000, foglio 080 Riva del Garda [Illustrative notes on Italian geological map 1:50.000, sheet 080 Riva del Garda]. Provincia Autonoma di Trento, LAC, Firenze, Italy, pp. 145.

Conedera M, Krebs P, Tinner W, Pradella M, Torriani D (2004). The cultivation of Castanea sativa (Mill.) in Europe. From its origin to its diffusion on a continental scale. Vegetation History and Archaeobotany 13 (3): 161-179. - doi: 10.1007 /s00334-004-0038-7

Costello LR, Perry EJ, Matheny NP, Henry JM, Geisel PM (2003). Abiotic disorders of landscape plants: a diagnostic guide. Agriculture and Natural Resources Publication no. 3420, University of California, Oakland, CA, USA, pp. 242.

Dengiz O, Ic S, Sarioglu FE (2011). Physico-chemical and morphological properties of soils for Castanea sativa in the central Black See region. International Journal of Agricultural Research 6 (5): 410-419. - doi: 10.3923/ijar.2011.410.419

Deng S, Hiruki C (1991). Amplification of $16 \mathrm{~S}$ rRNA genes from culturable and nonculturable Mollicutes. Journal of Microbiological Methods 14: 53-61. - doi: 10.1016/0167-7012(91)90007-D 
Drouineau J (1942). Dosage rapide du calcaire actif de sols [Rapid dosage of active limestone in soils]. Annales Agronomiques 12: 441-450. [in French]

EPPO (2001). EPPO alert list. Web site. [online] URL: http://www.eppo.org/

Gehring E, Bellosi B, Quacchia A, Conedera M (2018). Assessing the impact of Dryocosmus kuriphilus on the chestnut tree: branch architec ture matters. Journal of Pest Science 91: 189202. - doi: 10.1007/s10340-017-0857-9

Han S, Kim YH, So IY, Chai JK (1997). Association of phytoplasma with chestnut (Castanea cre nata Sieb. et Zucc.) little leaf disease in Korea. Korean Journal of Mycoplasmology 8: 48-54.

INFC (2007a). Le stime di superficie 2005 - Prima parte [Surfaces estimation 2005 - first part] (Tabacchi G, De Natale F, Di Cosmo L, Floris A, Gagliano C, Gasparini P, Genchi L, Scrinzi G, Tosi $V$ eds). Inventario Nazionale delle Foreste e de Serbatoi Forestali di Carbonio, MiPAF - Corpo Forestale dello Stato - Ispettorato Generale, CRA - ISAFA, Trento. [in Italian] [online] URL: http://www.infc.it

INFC (2007b). Le stime di superficie 2005 - Sec onda parte [Surfaces estimation 2005 - second part]. (Tabacchi G, De Natale F, Di Cosmo L, Floris A, Gagliano C, Gasparini P, Salvadori I, Scrinzi G, Tosi V eds). Inventario Nazionale delle Foreste e dei Serbatoi Forestali di Carbonio, MiPAF - Corpo Forestale dello Stato - Ispettorato Generale, CRA - ISAFA, Trento, Italy. [in Italian] [online] URL: http://www.infc.it

ISO-10693 (1995). Soil quality - determination of carbonate content - Volumetric method. International Organisation for Standardization, Geneva, Switzerland, pp. 7.

Jung H-Y, Sawayanagi T, Kakizawa S, Nishigawa H, Miyata S-I, Oshima K, Ugaki M, Lee J-T, Hibi T, Namba S (2002). "Candidatus Phytoplasma castaneae", a novel phytoplasma taxon associ ated with chestnut witches' broom disease. International Journal of Systematic and Evolu tionary Microbiology 52: 1543-9. - doi: 10.1099/ 002 7713-52-5-1543

Laroche A, Freyssac V, Rahmani A, Verger JP, Morvan H (1997). Growth and mineral content of young chestnut trees under controlled conditions of nutrition. Annales des Sciences Forestières 54: 681-693. - doi: 10.1051/forest:19970 708

Lee I-M, Hammond RW, Davis RE, Gundersen DE (1993). Universal amplification and analysis of pathogen $16 \mathrm{~S}$ rDNA for classification and identification of mycoplasmalike organisms. Phytopathology 83: 834. - doi: 10.1094/Phyto-83-834 Lindsay WL, Norwell WA (1969). Development of a DTPA micronutrient soil test. Agronomy Ab- stract 69: 87 .

Lin CL, Li HF, Zhang GZ, Wei W, Zhu XQ, Li ZP, Wang H, Xu QC, Zhou T, Tian GZ (2011). Molecular identification and characterization of a new phytoplasma strain associated with Chinese chestnut yellow crinkle disease in China. Forest Pathology 41: 233-236. - doi: 10.1111/j.1439-032 9.2010.00679.x

Maltoni A, Mariotti B, Tani A (2012). Case study of a new method for the classification and analysis of Dryocosmus kuriphilus Yasumatsu damage to young chestnut sprouts. iForest 5: 5059. - doi: 10.3832/iforo598-008

Mittempergher L, Sfalanga A (1998). Chestnut yellows: a new disease for Europe. Phytopathologia Mediterranea 37: 143-145. [online] URL: http://www.jstor.org/stable/42685339

Okuda S, Doi Y, Yora K (1974). Mycoplasma-like bodies associated with chestnut yellows. Annals of the Phytopathological Society of Japan 40: 464-468. [in Japanese]

Pezzi G, Donati D, Muzzi E, Conedera M, Krebs P (2019). Using chorographic sources to reconstruct past agro-forestry systems. A methodological approach based on the study case of the northern Apennines. Landscape Research 45 (3): 359-376. - doi: 10.1080/01426397.2019.16 24700

Pezzi G, Lucchi E, Maresi G, Ferretti F, Viaggi D, Frascaroli $F$ (2017). Abandonment or survival? Understanding the future of Castanea sativa stands in function of local attitude (Northern Apennine, Italy). Land Use Policy 61: 564-574. doi: 10.1016/j.landusepol.2016.10.049

Pezzi G, Maresi G, Conedera M, Ferrari C (2011). Woody species composition of chestnut stands in the Northern Apennines: the result of 200 years of changes in land use. Landscape Ecology 26 (10): 1463-1476. - doi: 10.1007/s10980-0119661-8

Portela E, Pires CC, Louzada J (2010). Magnesium deficiency in chestnut groves: the influence of soil manganese. Journal of Plant Nutrition 33 (3): 452-460. - doi: 10.1080/01904160903470489 Quacchia A, Moriya S, Bosio S, Alma A (2008). Rearing, release and settlement prospect in Italy of Torymus sinensis, the biological control agent of the chestnut gall wasp Dryocosmus kuriphilus. BioControl 53 (6): 829-839. - doi: 10.1007/s10526-007-9139-4

Schneider B, Seemüller E, Smart CD, Kirkpatrick BC (1995). Phylogenetic classification of plant pathogenic mycoplasma-like organisms or phytoplasmas. In: "Molecular and Diagnostic Procedures in Mycoplasmology" (Razin S, Tully JG eds). Academic Press, San Diego, CA, USA, pp. 369-380.

Seemüller E, Marcone C, Lauer U, Ragozzino A,
Göschl M (1998). Current status of molecular classification of the phytoplasmas. Journal of Plant Pathology 80 (1): 3-26. [online] URL: http://www.jstor.org/stable/41997897

Shimada C, Kouda S (1954). Yellowing disease of chestnut. Annals of the Phytopathological Society of Japan 19: 95.

Toprak S (2019). The macro and micro nutrition status of Anatolian chestnut in Inegol (BursaTurkey). Eurasian Journal of Forest Science 7 (2): 121-132. - doi: 10.31195/ejejfs.535803

Toprak S, Seferoglu S (2013). The seasonal changes of nutritional elements of chestnut (Castanea sativa) plant and determination of leaf sampling times. American Journal of Research Communication 1 (5): 1-8. [online] URL: http://www.semanticscholar.org/paper/0986e7 bc2bcooge78df49f13d36fb9285f3ed3cb?p2df

Turchetti T, Ferretti F, Maresi G (2008). Natural spread of Cryphonectria parasitica and persistence of hypovirulence in three Italian coppiced chestnut stands. Forest Pathology 38 (4): 227-243. - doi: 10.1111/j.1439-0329.2008.00557.x Ugolini F, Massetti L, Pedrazzoli F, Tognetti R, Vecchione A, Zulini L, Maresi G (2014). Ecophysiological responses and vulnerability to other pathologies in European chestnut coppices, heavily infested by the Asian chestnut gall wasp. Forest Ecology and Management 314 (1): 38-49. - doi: 10.1016/j.foreco.2013.11.031 Vettraino AM, Vannini A, Flamini L, Lagnese R, Pizzichini L, Talevi S, Fulbright DW (2005). A new transmissible symptomology on sweet chestnut in Italy. Acta Horticulturae: 547-550. doi: 10.17660/ActaHortic.2005.693.71

Vittori Antisari L, Falsone G, Carbone S, Vianello $G$ (2013). Short-term effects of forest recovery on soil carbon and nutrient availability in an experimental chestnut stand. Biology and Fertility of Soils 49 (2): 165-173. - doi: 10.1007/s00374-01 2-0708-z

\section{Supplementary Material}

Fig. S1 - Tree no. 19 in 2015 (a) and after a complete recovery in summer 2018 (b).

Fig. S2 - Overall effect of different irrigation regimes on the three tested soil thesis.

Tab. S1 - Chemical characteristics of soils under healthy and yellowing trees.

Tab. S2 - Macro and micro-nutrient contents of healthy and yellowing leaves.

Link: Bertoldi_3488@supplo01.pdf 